Vol. 2, No. 2, Juli - Desember 2018

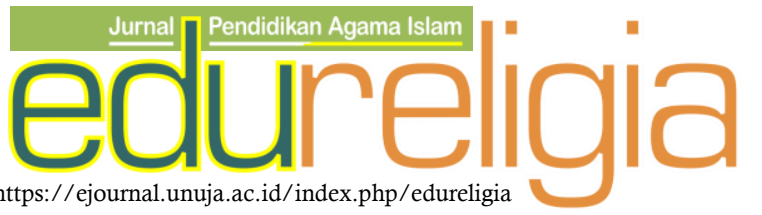

\title{
PERAN TEKNOLOGI DALAM PENDIDIKAN DI ERA GLOBALISASI
}

\author{
Sudarsri Lestari ${ }^{1}$ \\ Institut Agama Islam Ibrahimy, Banyuwangi
}

\section{Info Artikel \\ Sejarah Artikel: \\ Diterima; Juni 2018 \\ Disetujui; Juli 2018 \\ Dipublikasikan; Agustus 2018}

Keywords:

technology; education; globalization

\begin{abstract}
The aim of the government in organizing education is to educate the life of the nation. Intelligence is needed by everyone to face the times that have entered the era of globalization.Education in the global era can be interpreted as the integration of national education into world education. In the era of globalization, the progress of the nation is largely determined by the use of science and technology. Technology that is developing now has entered the digital era, where all fields have utilized technology to facilitate work, including in the field of education. Educational technology is a system that is used to support learning so that desired results are achieved. The role of technology in education is implemented in the use of learning media, administrative tools, and lerning resources. The positive impact of technology implementation in education is more efficient in terms of time, cost, logistics and other institutional problems, while the negative impact is that technology can change social life.
\end{abstract}

C 2018 Fakultas Agama Islam Universitas Nurul Jadid

Email :lilis@iaiibrahimy.ac.id 


\section{PENDAHULUAN}

Ilmu pengetahuan semakin berkembang dari masa ke masa. Perkembangan ilmu pengetahuan ini mendukung untuk terciptanya teknologi-teknologi baru yang menandai adanya kemajuan zaman. Hingga kini, teknologi yang berkembang sudah memasuki tahap digital. Termasuk di Indonesia, setiap bidang sudah mulai memanfaatkan teknologi untuk memudahkan pekerjaan, termasuk juga di bidang pendidikan.

Sebagai suatu entitas yang terkait dalam budaya dan peradaban manusia, pendidikan di berbagai belahan dunia mengalami perubahan sangat mendasar dalam era globalisasi. Ada banyak kemajuan ilmu pengetahuan dan teknologi yang bisa dinikmati umat manusia. Namun sebaliknya,kemajuan tersebut juga beriringan dengan kesengsaraan banyak anak manusia, apalagi dalam era globalisasi sekarang ini.

Teknologi merupakan hasil dari perkembangan ilmu pengetahuan, yang terjadi di dunia pendidikan. Oleh karena itu, sudah selayaknya pendidikan sendiri juga memanfaatkan teknologi untuk membantu pelaksanaan pembelajaran. Hal ini sesuai dengan pendapat Tondeur et al (dalam Selwyn, 2011) yang menyatakan bahwa teknologi digital kini sudah mulai digunakan di dalam lembaga pendidikan sebagai sarana untuk mendukung pembelajaran, baik sebagai alat informasi (yaitu sebagai sarana mengakses informasi) atau sebagai alat pembelajaran (yaitu sebagai sarana penunjang kegiatan belajar dan tugas).

Teknologi merupakan hasil ciptaan manusia. Oleh karena itu, wajar bila memiliki kekurangan atau dampak negatif. Di dalam bidang pendidikan, selain memiliki sisi positif, teknologi juga memiliki sisi negatif.

\section{PEMBAHASAN}

\section{Pendidikan di Era Globalisasi}

Pendidikan adalah usaha sadar dan terencana untuk mewujudkan suasana belajar dan proses pembelajaran agar peserta didik secara aktif mengembangkan potensi dirinya untuk memiliki kekuatan spiritual keagamaan, pengendalian diri, kepribadian, kecerdasan, akhlak mulia, serta keterampilan yang diperlukan dirinya, masyarakat, bangsa dan negara (UU no.20 th 2003 pasal 1:1). Pemerintah menyelenggarakan pendidikan bertujuan untuk mencerdaskan kehidupan bangsa. Kecerdasan itu diperlukan oleh setiap orang untuk menghadapi perkembangan zaman yang sudah memasuki era globalisasi.

Menurut Grew (dalam Nikolopoulou 2010:28) globalisasi secara luas dipahami sebagai peregangan kegiatan sosial, politik dan ekonomi lintas batas sehingga kejadian, keputusan dan kegiatan yang berlangsung di suatu temapat atau suatu wilayah memiliki arti penting bagi masyarakat keseluruhan. Kemudian pengertian secara luas globalisasi adalah proses pertumbuhan negara-negara maju (Amerika, Eropa dan Jepang) melakukan ekspansi besar-besaran, Kemudian berusaha mendominasi dunia dengan kekuatan teknologi, ilmu pengetahuan, politik, budaya, militer dan ekonomi.

Dalam bidang ekonomi, globalisasi ekonomi berarti terintegrasinya ekonomi nasional ke dalam ekonomi dunia atau global. Bila dikaitkan dalam bidang pendidikan, globalisasi pendidikan berarti terintegrasinya pendidikan nasional ke dalam pendidikan dunia.

Bila dipelajari lebih jauh, globalisasi membawa pengaruh terhadap negara-negara berkembang yang baru terlepas dari belenggu penjajahan, baik positif maupun negatif. Pengaruh positif dari globalisasi yaitu membantu/mendorong negara-negara baru berkembang untuk maju secara teknis, serta menjadi lebih sejahtera secara material. Sedangkan pengaruh negatifnya adalah munculnya teknokrasi yang sangat berkuasa, didukung oleh alat-alat teknik modern dan persenjataan yang canggih.

Pendekatan sistem perlu dipergunakan dalam menjelaskan pendidikan, karena pada era global sekarang ini dunia pendidikan telah berkembang sedemikian rupa sehingga menjadi hal ikhwal. Toffler (1992:4) menyatakan bahwa sekolah atau lembaga pendidikan masa depan harus mengarahkan peserta didiknya untuk belajar bagaimana belajar (learn how learn).

Kebutaan dalam era global adalah ketidakmampuan bagaimana belajar. Ciri utama manusia Indonesia masa depan adalah manusia yang mendidik diri sendiri sepanjang hayat dan masyarakat belajar yang terbuka tetapi memiliki pandangan hidup yang mantap. Maka peserta didik harus dibekali informasi tentang latar belakang yang memberi dampak pengganda pada pembelajarannya sehingga dapat memberikan motivasi yang besar untuk membaca dan mempelajari informasi dari berbagai sumber. 
Tantangan Pendidikan di Era Globalisasi

Dewasa ini globalisasi sudah mulai menjadi permasalahan aktual pendidikan. Beberapa tantangan pendidikan di era globalisasi yang pertama adalah kualitas pendidikan. Permasalahan globalisasi dalam bidang pendidikan terutama menyangkut output pendidikan. Seperti diketahui, di era globalisasi dewasa ini telah terjadi pergeseran paradigma tentang keunggulan suatu negara, dari keunggulan komparatif (comperative adventage) kepada keunggulan kompetitif (competitive advantage). Keunggulam komparatif bertumpu pada kekayaan sumber daya alam, sementara keunggulan kompetitif bertumpu pada pemilikan sumber daya manusia (SDM) yang berkualitas artinya dalam konteks pergeseran paradigma keunggulan tersebut, pendidikan nasional akan menghadapi situasi kompetitif yang sangat tinggi, karena harus berhadapan dengan kekuatan pendidikan global.

Kedua, peofesionalisme tenaga kependidikan. Salah satu komponen penting dalam kegiatan pendidikan dan proses pembelajaran adalah pendidik atau guru. Betapapun kemajuan teknologi telah menyediakan berbagai ragam alat bantu untuk meningkatkan efektifitas proses pembelajaran, namun posisi guru tidak sepenuhnya dapat tergantikan. Itu artinya guru merupakan variabel penting bagi keberhasilan pendidikan.

Ketiga, kebudayaan atau akulturasi. Suatu perkembangan kebudayaan dalam abad modern saat ini adalah tidak dapat terhindar dari pengaruh kebudayan bangsa lain. Kondisi demikian menyebabkan timbulnya proses alkulturasi yaitu pertukaran dan saling berbaurnya antara kebudayaan yang satu dengan yang lainnya. Dari sinilah terdapat tantangan bagi pendidikanpendidikan yaitu dengan adanya alkulturasi tersebut maka akan mudah masuk pengaruh negatif bagi kebudayaan, moral dan akhlak anak. Oleh karena itu hal ini merupakan tantangan bagi pendidikan untuk memfilter budaya-budaya yang masuk agar tidak terkena dampak negatif dari masuknya budaya asing.

Keempat, strategi pembelajaran. Era globalisasi dewasa ini mempunyai pengaruh yang sangat signifikan terhadap pola pembelajaran yang mampu memberdayakan para peserta didik. Tuntutan global telah mengubah paradigma pembelajaran dari paradigma pembelajaran tradisional ke paradigma pembelajaran modern, namun namun kenyataannya menunjukkan praktek pembelajaran lebih banyak menerapkan strategi pembelajaran tradisional dari pembelajaran baru. Hal ini agaknya berkaitan erat dengan rendahnya professionalisme guru.

Kelima, perbaikan manajemen. Perbaikan manajemen pendidikan dan manajemen sekolah diarahkan untuk lebih memberdayakan lembaga-lembaga pendidikan dan sekolah sebagai unit pelaksanaan terdepan dalam kegiatan belajar mengajar disekolah.

Keenam, akses pendidikan. Salah satu kebijakan pemerintah di bidang pendidikan adalah terlaksananya wajib belajar Pendidikan Dasar 9 tahun yang sekarang sudah menuju wajib belajar 12 tahun. Keberhasilan implementasi kebijakan ini mempunyai dampak strategis sebagai salah satu upaya meningkatkan kualitas sumber daya manusia Indonesia.

Ketujuh, kemajuan ilmu pengetahuan dan teknologi. Sebagaimana telah kita sadari bersama bahwa dampak positif dari pada kemajuan teknologi sampai kini adalah bersifat fasilitatif (memudahkan). Teknologi menawarkan berbagai kesantaian dan ketenangan yang semakin beragam.

\section{Pengertian Teknologi Pendidikan}

Penggunaan teknologi sudah bukan hal yang asing lagi di dalam era globalisasi. Termasuk di dunia pendidikan, sebagai tempat lahirnya teknologi, sudah sewajarnya bila pendidikan juga memanfaatkan teknologi untuk memudahkan pelaksanaan pembelajaran. Dari sini, muncul lah istilah teknologi pendidikan.

Teknologi pendidikan adalah metode bersistem untuk merencanakan, menggunakan, dan menilai seluruh kegiatan pengajaran dan pembelajaran dengan memperhatikan, baik sumber teknis maupun manusia dan interaksi antara keduanya, sehingga mendapatkan bentuk pendidikan yang lebih efektif (Kamus Besar Bahasa Indonesia). Sedangkan menurut Yusuf (2012) teknologi pendidikan adalah suatu proses sistemik dalam membantu memecahkan masalah-masalah pembelajaran. Pendapat ini sejalan dengan pendapat Muffoletto (dalam Selwyn, 2011) yang menyatakan bahwa teknologi pendidikan bukan tentang perangkat, mesin, komputer atau artefak lainnya, melainkan itu adalah tentang sistem dan proses yang mengarah ke hasil yang diinginkan. Dari beberapa pendapat di atas dapat dikatakan teknologi pendidikan adalah suatu sistem yang dimanfaatkan untuk menunjang 
pembelajaran sehingga tercapai hasil yang diingingkan.

\section{Implementasi Teknologi dalam Pendidikan di Era Globalisasi}

Berdarkan pengertian teknologi pendidikan di atas, maka dapat dikatakan bahwa teknologi dimanfaatkan sebagai penunjang keberhasilan pembelajaran. Berikut beberapa contoh implementasi teknologi dalam pendidikan.

1. Media pembelajaran

Kata media merupakan bentuk jamak dari kata medium. Medium dapat didefinisikan sebagai perantara atau pengantar terjadinya komunikasi dari pengirim menuju penerima (Heinich et.al, 2002). Sedangkan media pembelajaran adalah sesuatu yang dapat digunakan untuk menyalurkan pesan (bahan pembelajaran), sehingga dapat merangsang perhatian, minat, pikiran, dan perasaan siswa dalam kegiatan belajar untuk mencapai tujuan belajar (Santyasa, 2007). Penggunaan teknologi sebagai media pembelajaran sudah tidak asing lagi, mulai dari teknologi yang sangat sederhana sampai teknologi yang canggih. Teknologi dapat dimanfaatkan untuk menarik minat siswa dalam belajar sehingga pembelajaran menjadi lebih efektif dan efisien.

Perkembangan ilmu pengetahuan telah membawa teknologi memasuki dunia digital. Menurut Selwyn (2011), penggunaan teknologi digital memiliki peran dalam mendukung dan meningkatkan proses kognitif peserta didik dan keterampilan berpikir. Salah satu contoh teknologi digital adalah internet. Internet dapat memungkinkan guru untuk menyajikan pelajaran menjadi lebih menarik bagi para peserta didik. Saat ini pembelajaran berbasis internet, seperti web-learning, e-learning atau pembelajaran online (pembelajaran jarak jauh) sudah banyak dilakukan. Pembelajaran-pembelajaran ini memanfaatkan internet sebagai media. Selain pembelajaran menjadi lebih fleksibel dari segi waktu, tempat dan usia, peserta didik juga dapat mengakses informasi yang dibutuhkan dalam pembelajaran dengan bebas. Karena pembelajaran menjadi lebih individual, maka hal ini dapat meningkatkan proses kognitif peserta didik dan keterampilan berpikirnya.

Contoh lain penggunaan teknologi sebagai media pembelajaran adalah radio, televisi, video yang dapat dimanfaatkan untuk memfasilitasi gaya belajar peserta didik yang berbeda-beda dan juga menarik minat siswa untuk dapat lebih termotivasi lagi dalam belajar. Penggunaan perangkat presentasi interaktif seperti papan tulis elektronik dapat membuat materi pembelajaran menjadi lebih menarik untuk peserta didik.

\section{Alat administratif}

Teknologi juga dapat dimanfaatkan sebagai alat administratif. Seperti yang dikatakan Selwyn (2011) bahwa salah satu manfaat teknologi digital adalah sebagai perbaikan keefektifan pengorganisasian lembaga pendidikan. Dengan menggunakan komputer, sebagai salah satu produk teknologi digital, lembaga pendidikan dapat lebih mudah untuk mengelola data administrasi, meliputi data siswa, data guru, maupun data sekolah itu sendiri.

\section{Sumber belajar}

Selwyn (2011) mengatakan teknologi digital dapat membantu guru untuk memproduksi bahan-bahan pelajaran dan memungkinkan mereka untuk menghabiskan waktu dengan peserta didik. Dengan tersedianya komputer, guru dapat menyusun rencana pembelajaran dan materi-materi yang dibutuhkan oleh peserta didik untuk dipelajari. Selain itu, tersedianya internet juga memungkinkan peserta didik untuk mengakses informasi dengan mudah dari sumber yang berbeda.

Saat ini, dengan menggunakan teknologi digital, peserta didik banyak mendapatkan kemudahan-kemudahan dalam belajar. tersedianya e-book merupakan salah salah satu salah satu kemudahan tersebut. Peserta didik tidak perlu membeli buku di toko-toko untuk mendapatkan sumber belajar. Peserta didik cukup hanya mendownload e-book yang sudah banyak tersedia di internet.

\section{Isu-Isu dalam Teknologi Pendidikan}

Teknologi di dalam perkembangannya, tentu membawa perubahan dalam kehidupan sehari-hari, termasuk perubahan di bidang pendidikan. Ada beberapa perdebatan terkait dengan dengan penggunaan teknologi di dalam pendidikan. Pertama, teknologi dapat meningkatkan pembelajaran. Salah satu penggunaan teknologi dalam pembelajaran adalah sebagai media pembelajaran, seperti multimedia interaktif. Menurut Heinich et al (2002) multimedia interaktif adalah suatu media yang terdiri gambar, suara, dan bahan-bahan video yang disajikan di bawah kontrol komputer untuk peserta didik, sehingga peserta didik tidak hanya melihat gambar dan mendengar suara tetapi juga membuat respon aktif. Respon tersebut mempengaruhi kecepatan dan urutan penyajian materi pembelajaran. Beberapa 
penelitian seperti yang dilakukan oleh Rahayuningrum (tt) dan Izzudin (2013) menyatakan bahwa penggunaan multimedia interaktif dapat meningkatkan pembelajaran yang ditandai dengan meningkatnya hasil belajar siswa. Namun, di sisi lain bila penggunaan teknologi tidak sesuai dengan yang dibutuhkan di dalam pembelajaran, atau tidak adanya kontrol guru dalam penggunaan teknologi selama pembelajaran, maka teknologi tersebut dapat menjadi bumerang. Sejumlah studi kuasi-eksperimen terpisah di SMA Israel, Jerman, Belanda dan Columbia semuanya melaporkan tidak ada pengaruh atau bahkan negatif antara tingkat penggunaan komputer dan hasil pembelajaran akhirnya (Angrist dan Lavy, 2002, Lauven et al. 2003, Fuchs dan Woessmann, 2004, Barrera-Osorio dan Linden, 2009 dalam Selwyn, 2011).

Isu kedua adalah teknologi dapat membuat pendidikan menjadi lebih baik. Seperti yang dikemukakan sebelumnya, bila teknologi dapat meningkatkan pembelajaran, maka teknologi juga akan membuat pendidikan lebih baik. Namun, teknologi seperti komputer juga dapat membuat kesenjangan sosial semakin tampak. Bagi peserta didik yang sudah paham dan terbiasa dalam mengoperasikan komputer, maka ia dapat dengan mudah menggunakannya untuk menunjang belajar sehingga mendapatkan hasil belajar yang maksimal. Sementara bagi peserta didik yang belum mengenal komputer dan belum bisa mengoperasikannya, maka belajarnya akan terfokus pada cara pengoperasian komputer, bukan pada materi yang seharusnya ia pelajari. Hal ini dapat menurunkan hasil belajarnya.

Isu ketiga adalah teknologi dapat menggantikan guru. Dengan adanya teknologi digital, pembelajaran dapat dilakukan dimana saja, kapan saja dan pada usia berapa saja. Internet menyediakan banyak informasi dari bermacam-macam sumber yang dapat dengan mudah diakses oleh peserta didik untuk memperluas pengetahuan mereka tentang suatu materi pembelajaran. Beberapa guru yang menerapkan pembelajaran berbasis web juga meminta peserta didiknya untuk mencari informasi yang dibutuhkan dalam pembelajaran di internet secara mandiri. Pendapat inilah yang menguatkan pernyataan teknologi dapat menggantikan guru. Memang benar internet menyediakan segala informasi yang dibutuhkan oleh peserta didik tentang suatu materi, namun tidak semua informasi yang disajikan di internet dapat menggantikan pengalaman belajar peserta didik bersama guru. Ada beberapa materi pembelajaran yang melibatkan peran guru secara langsung sebagai role model ataupun sebagai pembimbing, seperti materi etika dan pidato, yang tidak dapat dilakukan oleh internet.

Isu keempat adalah teknologi dapat menggantikan sekolah. Adanya teknologi internet dapat dimanfaatkan untuk pembelajaran jarak jauh, yaitu pembelajaran melalui telekomunikasi (Heinich et al, 2002). Dalam pembelajaran jarak jauh ini, tidak mengharuskan peserta didik duduk di dalam kelas reguler. Peserta didik dapat mengikuti pembelajaran dimanapun dan kapanpun, sehingga pembelajaran menjadi lebih fleksibel. Pembelajaran jarak jauh merupakan solusi bila peserta didik maupun guru tidak dapat bertatap muka secara langsung disebabkan keterbatasan waktu dan tempat. Namun, di sisi lain pembelajaran jarak jauh dapat menyebabkan peserta didik menjadi lebih individualis. Selain itu, keterampilan berbicara dan bersosialisasi juga tidak akan didapat dari pembelajaran jarak jauh. Oleh sebab itu, penggunaan teknologi dalam pendidikan memang dapat mempermudah jalannya suatu pendidikan, namun teknologi belum tentu dapat menyelesaikan semua persoalan yang berkaitan dengan pendidikan seperti pembelajaran sosial.

\section{Dampak Teknologi dalam Pendidikan di Indonesia}

Berkembangnya teknologi yang semakin canggih tentu diikuti dengan beberapa dampak, baik dampak positif maupun dampak negatif. Ada banyak pendapat yang berkaitan dengan pemanfaatan teknologi dalam pendidikan. Nicholas Gane (dalam Selwyn, 2011) berpendapat bahwa teknologi internet terkait secara langsung dalam mengubah pola kehidupan sehari-hari, termasuk cara bekerja, akses dan pertukaran informasi, berbelanja, bertemu orang-orang, dan memelihara dan mengatur hubungan sosial yang ada. Adanya internet memudahkan seseorang berkomunikasi tanpa dibatasi ruang dan waktu. Dengan adanya internet, seseorang juga dapat belajar atau menempuh pendidikan jarak jauh dengan mudah. Namun, tidak dapat dipungkiri bahwa hal ini dapat mengubah tatanan sosial di masyarakat, seperti dapat merubah seseorang menjadi lebih individualis dan apatis terhadap keadaan sekitar mereka. 
Selwyn (2011) mengatakan bahwa teknologi telah melakukan lebih dari sekedar 'menambah' pengaturan sosial yang ada; teknologi telah secara radikal mengubah tiga bidang utama kehidupan sosial, lingkup produksi, konsumsi dan komunikasi. Dalam dunia pendidikan, salah satu keterampilan yang dipelajari adalah keterampilan berbicara dan berkomunikasi. Jika pembelajaran dilakukan dengan melalui internet atau media interaktif, maka ketererampilan peserta didik dalam berkomunikasi akan berkurang, sebab mereka hanya berinteraksi dengan mesin.

Clark (dalam Selwyn, 2011) mengatakan bahwa teknologi hanya sebagai kendaraan untuk menyampaikan pengajaran dan karena itu tidak lebih mungkin untuk mempengaruhi belajar siswa atau prestasi daripada sebagai sebuah truk yang menghadirkan segala kebutuhan untuk memperbaiki gizi. Sehingga, teknologi dalam pendidikan hanya berada pada posisi media atau perantara untuk mencapai tujuan pembelajaran yang diharapkan oleh suatu lembaga pendidikan. Peserta didik yang dapat memanfaatkan teknologi dengan baik untuk menambah pengetahuan maupun keterampilannya, maka ia akan mendapat prestasi yang bagus. Sebaliknya, jika peserta didik tidak tahu bagaimana cara memanfaatkan teknologi untuk menambah pengetahuan maupun keterampilannya, maka ia tidak akan mendapat prestasi yang bagus bahkan teknologi dapat berpengaruh negatif terhadap peserta didik tersebut. Namun di sisi lain, Clark (dalam Selwyn, 2011) mengakui bahwa ada manfaat ekonomis yang signifikan yang bisa didapat dari penggunaan teknologi untuk menyampaikan pembelajaran, yaitu manfaat dari waktu, biaya, logistik dan masalah kelembagaan lainnya. Salah satu contoh dampak positif dari teknologi dalam pendidikan adalah dapat diselenggarakannya pendidikan jarak jauh. Pendidikan jarak jauh mengatasi masalah perbedaan waktu, geografi dan biaya. Sehingga peserta didik yang memiliki keterbatasan geografi, seperti tempat tinggal yang jauh dari lembaga pendidikan sehingga membutuhkan biaya yang besar dan waktu yang lama untuk mendatanginya, tetap mendapatkan pendidikan sebagaimana pendidikan yang dilaksanakan secara reguler. Peraturan mengenai pendidikan jarak jauh juga diatur di dalam pasal 31 UU no.20 tahun 2003 tentang sistem pendidikan nasional.

\section{KESIMPULAN}

Pendidikan di era globalisasi berarti terintegrasinya pendidikan nasional ke dalam pendidikan dunia. Siswa harus dibekali kompetensi yang memadai agar siswa eksis di era global yang sangat kompetitif. Terdapat beberapa msalah dan tantangan yang dihadapi dunia pendidikan di era globalisasi, antara lain kualitas pendidikan, profesionalisme tenaga kependidikan, kebudayaan (akulturasi), strategi pembelajaran, tantangan perbaikan manajemen, serta tantangan kemajuan ilmu pengetahuan dan teknologi.

Teknologi dalam dunia pendidikan adalah suatu sistem yang dimanfaatkan untuk menunjang pembelajaran sehingga tercapai hasil yang diingingkan. Implementasi teknologi dalam pendidikan di Indonesia adalah teknologi dapat dimanfaatkan sebagai media pembelajaran, alat administratif, dan sumber belajar.

Dampak teknologi dalam pendidikan di Indonesia, selain memiliki dampak positif juga memiliki dampak negatif. Dampak positifnya adalah lebih efisien dalam masalah waktu, biaya, logistik dan masalah kelembagaan lainnya. Sedangkan dampak negatifnya adalah teknologi dapat merubah kehidupan sosial.

\section{DAFTAR PUSTAKA}

Heinich, R., Molenda, M., Russell, J. D., Smaldino, S. E. 2002. Instructional Media and Technologies for Learning. New Jersey: Pearson Education.

Izzudin, Ahmad Maulana. 2013. Efektivitas Penggunaan Media Pembelajaran Video Interaktif untuk Meningkatkan Hasil Belajar Praktik Service Engine dan KomponenKomponennya. Skripsi. Semarang: Universitas Negeri Semarang (Online),(http://lib.unnes.ac.id/188 40/1/5201409006.pdf) diakses pada tanggal 25 November 2018.

Kamus Besar Bahasa Indonesia (Online). http://kbbi.web.id/ diakses pada 23 November 2018.

Nikolopoulou,A. 2010. Education for Sustainable Development: challenges, strategies, and practices in a globalizing world. New Delhi: Vivek Mehra.

Rahayuningrum, Rosalia Hera. Tanpa tahun. Penggunaan Media Pembelajaran Multimedia Interaktif Berbantuan Komputer untuk Meningkatkan Motivasi Belajar dan Kemampuan Pemecahan Masalah Matematika Siswa Kelas VIIF di 
SMP Negeri 2 Imogiri Bantul. Makalah disajikan dalam lomba dan seminar matematika XIX UNY (Online),(http://eprints.uny.ac.id/6 969/1/Makalah\%20Peserta $\% 205 \% 2$ 0\%20Rosalia\%20Hera\%20Rahayuni ngrum,\%20S.Pd.pdf) diakses pada tanggal 25 November 2018.

Santyasa, I Wayan. 2007. Landasan Konseptual Media Pembelajaran. Makalah disajikan dalam workshop media pembelajaran bagi guru-guru SMA Negeri Banjar Angkan Klungkung, Bali 10 Januari 2007. (Online),(http://file.upi.edu/Direkt ori/FIP/JUR._PEND._LUAR_SE KOLAH/194704171973032MULIATI_PURWASASMITA/M EDIA_PEMBELAJARAN.pdf) diakses pada 25 November 2018.

Selwyn, Neil. 2011. Education and Technology Key Issues and Debates. India: Replika Press Pvt Ltd.

Toffler, A.1992. The Future Shock.

Terjemahan Hermawan Sulistyo. Jakarta: Pantja Simpati.

Yusuf, Moh. 2012. Peranan Teknologi Pendidikan dalam Peningkatan Mutu Pendidikan. Jurnal Ilmu Pendidikan, (Online), 1 (1): 65-74. (http://www.uinalauddin.ac.id/do wnload6.\%20M.\%20Yusuf\%20T._P ERANAN\%20TEKNOLOGI.pdf) diakses pada 23 November 2018. 